\title{
Root Growth Phenology, Root Longevity, and Rhizosphere Respiration of Field Grown 'Mutsu' Apple Trees on 'Malling 9' Rootstock
}

\author{
Georgios Psarras, Ian A. Merwin, ${ }^{1}$ Alan N. Lakso, and John A. Ray \\ Department of Horticulture, Cornell University, Ithaca, NY 14853
}

\begin{abstract}
AdDitional INDEX words. Malus sylvestris var. domestica, tree carbon balance, root physiology, root distribution, soil-root respiration

Abstract. A 2-year field study of 'Mutsu' apple [Malus sylvestris (L.) Mill. var. domestica (Borkh.) Mansf.] on 'Malling 9' (M.9) rootstock was conducted to observe root growth in situ, and compare patterns of root growth, root maturation and turnover rates, and soil-root respiration. Rhizosphere respiration was monitored with a portable chamber connected to an infrared gas analyzer; root emergence, browning, and turnover rates were measured by direct observation through minirhizotron tubes inserted in the root zone. Negligible root growth was observed before the onset of shoot growth in mid-May. In both years, a main peak of new root emergence in late June and early July coincided partially with major phases of shoot and fruit growth. A smaller peak of root emergence during August to September 1997 consisted primarily of new roots at 20 to $45 \mathrm{~cm}$ soil depths. Most roots remained $<1 \mathrm{~mm}$ in diameter and developed in the upper $25 \mathrm{~cm}$ soil profile; no roots were observed at any time below $50 \mathrm{~cm}$, due to a compacted soil layer at that depth. The cumulative survivorship of new roots was $38 \%$ in 1996 and $64 \%$ in 1997, and $50 \%$ of emergent white roots turned brown or senesced within 26 days in 1996 and 19 days in 1997. Root turnover rates were highest in mid-August both years. Rhizosphere respiration was correlated $\left(r^{2}=0.36\right.$ and $0.59, P=0.01$ and 0.004$)$ with soil temperatures in 1996 and 1997 , with $Q_{10}$ values of 2.3 in both years. The $Q_{10}$ for root-dependent respiration (the difference between soil only and combined soil-root respiration) in 1997 was 3.1 , indicating that roots were more sensitive than soil microflora to soil temperature. The temporal overlap of high rates of shoot, root and fruit growth from late May to mid-July suggests this is a critical period for resource allocations and competition in temperate zone apple trees.
\end{abstract}

Direct observation and nondestructive measurement of root growth and metabolism are difficult under field conditions. Information on growth of apple (Malus sylvestris var. domestica) roots is limited, and based largely on research in the United Kingdom from 1930 to 1980, as reviewed by Atkinson (1980). Lacking more definitive data, the bimodal pattern of apple root growth reported by Head $(1966,1967,1969)$ for 'Worcester Pearmain' apple trees on Malling-Merton 104 (MM.104) rootstocks has been tacitly accepted as the norm.

Portable respiration chambers that measure combined soilroot (rhizosphere) respiration in situ have recently been developed and used to study root respiration in relation to whole-tree carbon balance of apple (Blanke, 1996, 1997a), and to correlate soil-surface $\mathrm{CO}_{2}$ flux with root density and depth in almond (Prunus amygdalus Batsch.) orchards (Ben-Asher et al., 1994a, 1994b). Rhizosphere respiration of potted fruit trees in sand reportedly increased during summer, peaking in June or August (Buwalda et al., 1992; Ebert and Lenz, 1991 ); but these researchers did not determine whether increased soil-root respiration represented greater root growth, root turnover, or higher soil temperatures and microbial activity during midsummer.

Direct observation of roots with video cameras in minirhizotron tubes can provide detailed information about temporal and spatial changes in root activity (McMichael and Taylor, 1987). This method is a cost-effective, nondestructive way to monitor root

Received for publication 25 Oct. 1999. Accepted for publication 19 June 2000. This paper is part of a PhD diss. of G. Psarras. We thank the Greek Foundation of Scholarships for partial financial support, and Marvin Pritts and Christopher Watkins for critical reviews of this manuscript. Mention of a trademark does not imply endorsement of the product named, or criticism of similar products not named.The cost of publishing this paper was defrayed in part by the payment of page charges. Under postal regulations, this paper therefore must be hereby marked advertisement solely to indicate this fact.

${ }^{1}$ Corresponding author. growth in situ. Research before the development of minirhizotrons suggested that apple root growth peaked before and after the main phase of shoot growth in early to midsummer (Cripps, 1970; Head, 1967). These seasonal patterns were affected by pruning (Rogers and Head, 1969) and rootstock genotype (Rogers, 1939), and presumably would vary across different climatic regions.

Senescence and degradation or turnover of roots depends on the capacity of perennial plants to sustain root biomass in the soil environment. Root turnover may be intensified or reduced by tree pruning and defoliation, pest and disease damage, and the soil microbial community (Bloomfield et al., 1996; Head, 1973). Fine-root longevity of trees reportedly varies from 1 week to 5 years, and may be shorter for deciduous than for evergreen species (Bloomfield et al., 1996). Reid et al. (1993) reported that only $8 \%$ of kiwifruit (Actinidia chinensis Planchon) roots survived for $>1$ year, suggesting that root turnover constitutes a major sink for carbon allocations and a substantial metabolic cost for trees.

Considering the paucity of data on root phenology and physiology in situ, the objectives of this study were to determine root emergence, senescence, and turnover rates of field-grown apple trees in a cool temperate climatic region, and to investigate the relationship between rhizosphere respiration, soil temperature, and observed activities of intact root systems under field conditions.

\section{Materials and Methods}

FirST YeAR OF EXPERIMENT. In Apr. 1996, 15 comparable 4year-old 'Mutsu' apple trees on M.9 rootstock were selected from two adjacent rows of 50 trees at an orchard in Ithaca, N.Y. The soil was a glacial lacustrine silty clay loam (mixed mesic Udic Hapludalf), with a compacted layer at a depth of 45 to $50 \mathrm{~cm}$. Trees were growing in 3-m-wide weed-free herbicide treated 
Table 1. Total fruit yields, yield efficiency, and trunk cross-sectional area (TCSA) of young field-grown 'Mutsu' apple trees on M.9 rootstocks during the 1996 and 1997 growing seasons.

\begin{tabular}{lccc}
\hline \hline & $\begin{array}{c}\text { Fruit yield } \\
\left(\mathrm{t} \cdot \mathrm{ha}^{-1}\right)\end{array}$ & $\begin{array}{c}\text { Fruit yield } \\
\text { per TCSA } \\
\left(\mathrm{kg} \cdot \mathrm{cm}^{-2}\right)\end{array}$ & $\begin{array}{c}\text { TCSA } \\
\left(\mathrm{cm}^{2}\right)\end{array}$ \\
\hline 1996 & 14.0 & 1.1 & $15.8 \mathrm{~b}^{\mathrm{z}}$ \\
1997 & 19.1 & 1.0 & $20.3 \mathrm{a}$ \\
Effect of year & $\mathrm{ns}^{\mathrm{y}}$ & $\mathrm{NS}$ & $*$ \\
\hline
\end{tabular}

${ }^{\mathrm{z}}$ Mean separation by protected LSD $(P \leq 0.05)$

${ }^{\mathrm{Y}}$ Factor effects nonsignificant (NS), or significant (*) at $P \leq 0.05$.

strips at a density of 800 trees/ha, and trained to a modified slender spindle form. The selected trees were hand-thinned $30 \mathrm{~d}$ after petal fall, leaving no more than one fruit per spur.

The initial intent of this experiment was to establish different irrigation treatments that would create low (irrigated at $-20 \mathrm{kPa}$ soil water potential), moderate (irrigated at -80 $\mathrm{kPa}$ ), and high (irrigated at $-200 \mathrm{kPa}$ ) levels of drought stress for tree-root systems. In May 1996, we constructed 3-m-wide rain exclusion tents of silver-colored tarps over the soil surface of each tree row; zippered cuts in tarps provided access for observations and measurement in the soil beneath each tree.

Abundant precipitation during 1996 resulted in substantial lateral movement of water into the soil under our rain exclusion tents. Weekly measurements of soil water potential with tensiometers (Irrometer Co., Riverside, Calif.) inserted at $15 \mathrm{~cm}$ beneath each tree from April to October 1996 showed no consistent effects of irrigation treatments on soil water potential; the observations on all 15 trees were consequently pooled for observations and data analyses.

Trunk cross-sectional area was measured 20 $\mathrm{cm}$ above the graft union in March and December each year. Eight lateral extension shoots were measured weekly during each growing season, and total yield and number of fruit per tree were recorded at harvest. Fruit diameter was measured on 10 designated fruit per tree from petal fall to harvest in 1996, but not 1997.

Root emergence and survival were monitored through a minirhizotron tube inserted into the soil at an angle of $45^{\circ}$, transecting the root system diagonally $\approx 50 \mathrm{~cm}$ from each trunk. Due to wet and muddy soil conditions during Spring 1996, the minirhizotron tubes could not be installed until the end of May. Our first root observations occurred early in June; thereafter the soil-root profile was videotaped at $\approx 7$ to 10 d intervals until 23 Oct. 1996.

To increase the sampling area, we observed three visual sectors in each tube: one with the video camera pointed toward the upper surface of the tube; a second at a right angle to the first one, looking toward the tree; and a third at a right angle to the first observation looking away from the tree. Gradient lines in each tube enabled us to locate and videotape identical soil-depth profiles and roots over time, with the camera lowered at $2 \mathrm{~cm}$ tube-length intervals (equivalent to $1.4 \mathrm{~cm}$ of vertical soil depth) for each set of three observations.

The diameter of each root, its depth, and approximate date of emergence, browning or decay, and its disappearance (if this occurred) were tabulated based upon sequential videotaped observations (Psarras, 1999). Repeated observations were recorded for individual roots in every tube. Roots observed for the first time on a certain date were considered as new roots; root senescence, longevity, and half-life estimates were based on observed lifespans of individual roots. Root turnover rates were calculated by

Fig. 1. (A) Fruit diameter and shoot growth rates, (B) root emergence and turnover rates, and $(\mathbf{C})$ soil-root respiration rates and soil temperature for 4-year-old 'Mutsu' trees on M.9 rootstocks during 1996. Symbols represent the mean $\pm \mathrm{SE}$ for 15 trees, 10 fruit per tree (fruit diameter), 8 shoots per tree (shoot length), root counts and turnover per day in 15 observation tubes, 3 respiration collars per tree (soil-root respiration), and 3 sampling sites around each tree at a $10-\mathrm{cm}$ soil depth (soil temperature).
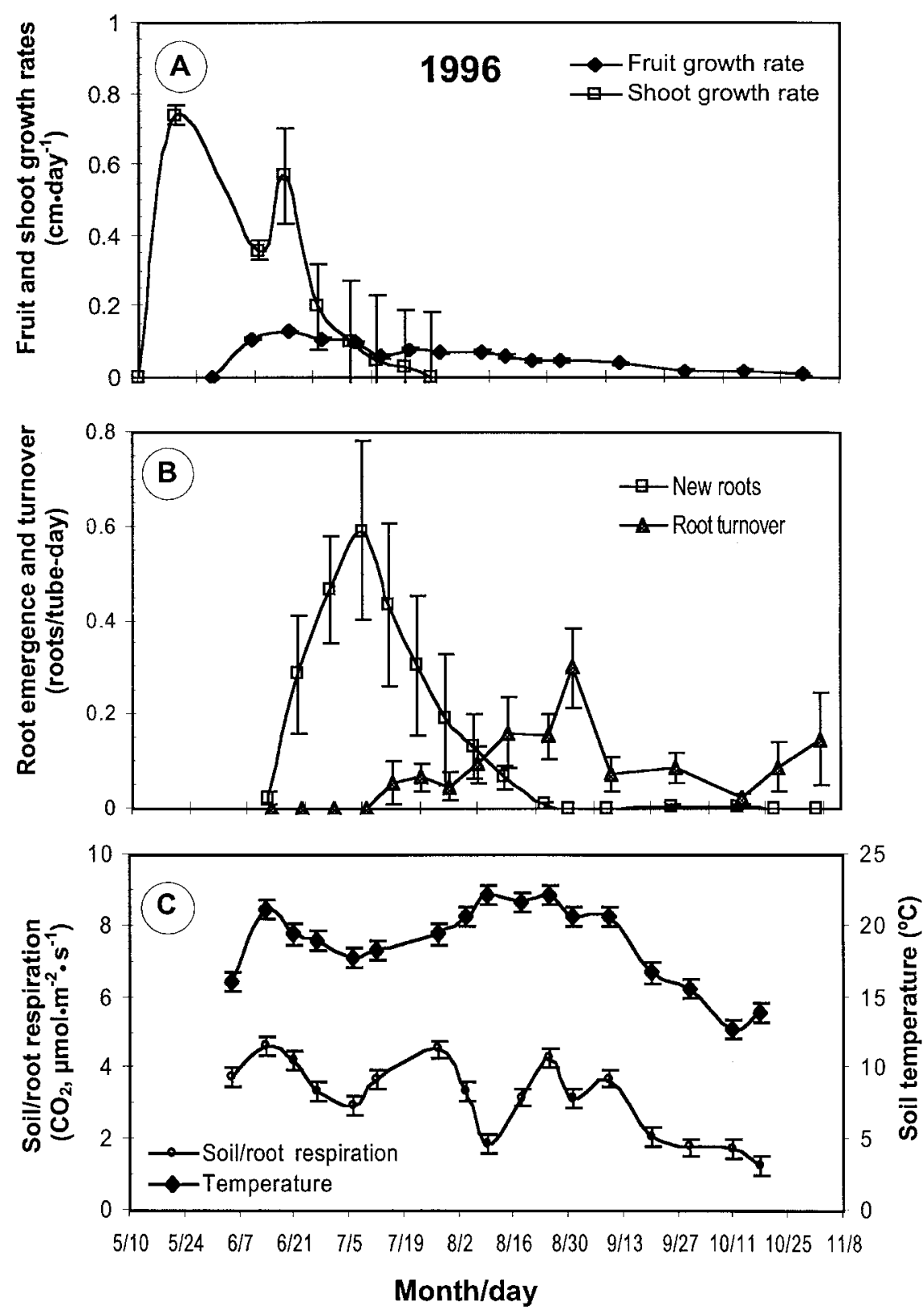
dividing the number of roots that disappeared between consecutive observations in each tube by the elapsed time (in days) between these two observations. We also recorded the number of days from root emergence to browning, which could represent senescence and decay, or progressive maturation into perennial roots (Atkinson, 1980). We did not continue root observations during the winter months, and could not determine the disposition or life-span of roots that turned brown late in the growing season and disappeared during winter.

Rhizosphere respiration was measured at approximately weekly intervals, using a portable photosynthesis system (LI-6200; LICOR Inc., Lincoln, Nebr.) connected to a soil-respiration chamber (LI-6000-09). Three measurements of $\mathrm{CO}_{2}$ efflux rate per soil-surface area $\left(\mu \mathrm{mol} \cdot \mathrm{m}^{-2} \cdot \mathrm{s}^{-1}\right)$ were taken beneath each tree by placing the respiration chamber over three $10-\mathrm{cm}$-diameter polyvinyl chloride (PVC) collars permanently inserted $10 \mathrm{~cm}$ deep into the soil, in a semicircle $\approx 25 \mathrm{~cm}$ away from the trunk. The upper $5 \mathrm{~cm}$ of soil in each PVC collar was removed and replaced by silica sand at the beginning of the experiment, and collars where left uncovered except during observations. Measurements always started around noon, and usually required $\approx 3 \mathrm{~h}$ to complete all 45 observations. The sequence of observations was always the same; i.e., repeated measurements for individual collars and trees were taken about the same time of day.

SECOND YEAR OF EXPERIMENT. The study was continued in 1997, with minor changes related to the water stress treatments. Irrigation and rain-exclusion treatments were not applied during 1997, but other observations were continued as before, under ambient soil water conditions. Soil water potential was recorded during each respiration measurement. The PVC collars and minirhizotron tubes had been sealed and left in place during the preceding dormant season; rhizosphere respiration and minirhizotron observations commenced 14 Apr. 1997, and were continued at 10 to $16-d$ intervals until the end of October. To reduce the effects of variable soil water content on $\mathrm{CO}_{2}$ efflux, and to minimize variation in root respiration that could be caused by photosynthetic preconditioning of trees during the days preceding observations (Buwalda et al., 1992), during the 1997 growing season we measured rhizosphere respiration on cloudless days preceded by at least 2 $\mathrm{d}$ of ample sunlight and no rainfall.

To provide reference observations of respiration in this field soil without tree roots, in Mar. 1997 we filled four 20-L perforated pots with soil excavated from the weed-free herbicide strip elsewhere at the site, reset these pots into the field soil, and conducted analogous soil respiration measurements in PVC collars inserted into each pot. Shoot growth, final yield, and fruit number were measured as before; but data for fruit diameter were not obtained during the second year because many of the tagged fruit were accidentally hand thinned by orchard workers.

Data analysis. As in other apple root demographic studies, root density was low and variability was often high, reflecting the inherent variability in tree root growth and distribution (Atkinson, 1980; McMichael and Taylor, 1987). Due to time and weather constraints, rhizotron video observations and rhizosphere respiration measurements could not be completed at the same time and were usually taken several days apart; statistical comparisons of these two measurements were therefore not appropriate. Fruit yield, tree growth, and yield efficiency were compared between years by analysis of variance. The $\mathrm{Q}_{10}$ values and correlations between soil or rhizosphere respiration and temperature were evaluated as linear regression models. To facilitate comparisons of measured parameters or trends with other published reports, we calculated shoot and fruit growth, root emergence and turnover rates on a per day basis, and data are presented without transformations.

Fig. 2. (A) Shoot growth rate, (B) root emergence and turnover rates, and (C) respiration rates in soil without roots and soil with roots, and soil temperature, for 5-year-old 'Mutsu' on M.9 rootstocks during 1997. Symbols represent the mean \pm SE for 15 trees, 5 shoots per tree (shoot length), root counts and turnover per day in 15 observation tubes, 3 respiration collars per tree (soil-root respiration), and 3 sampling sites around each tree at a10-cm soil depth (soil temperature). Respiration rates for soil in pots without roots represent the mean \pm sE of four pots.
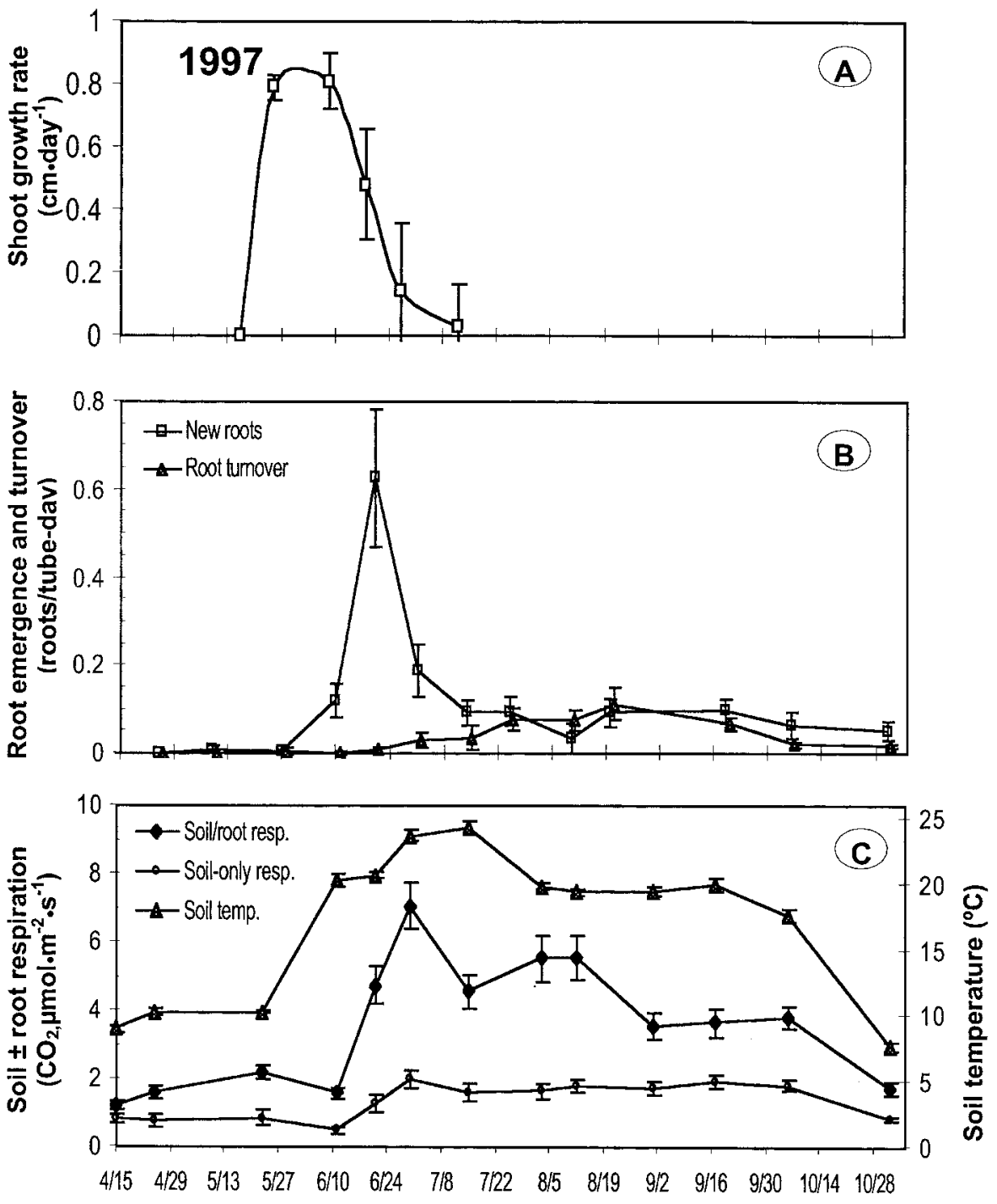

Month/day 

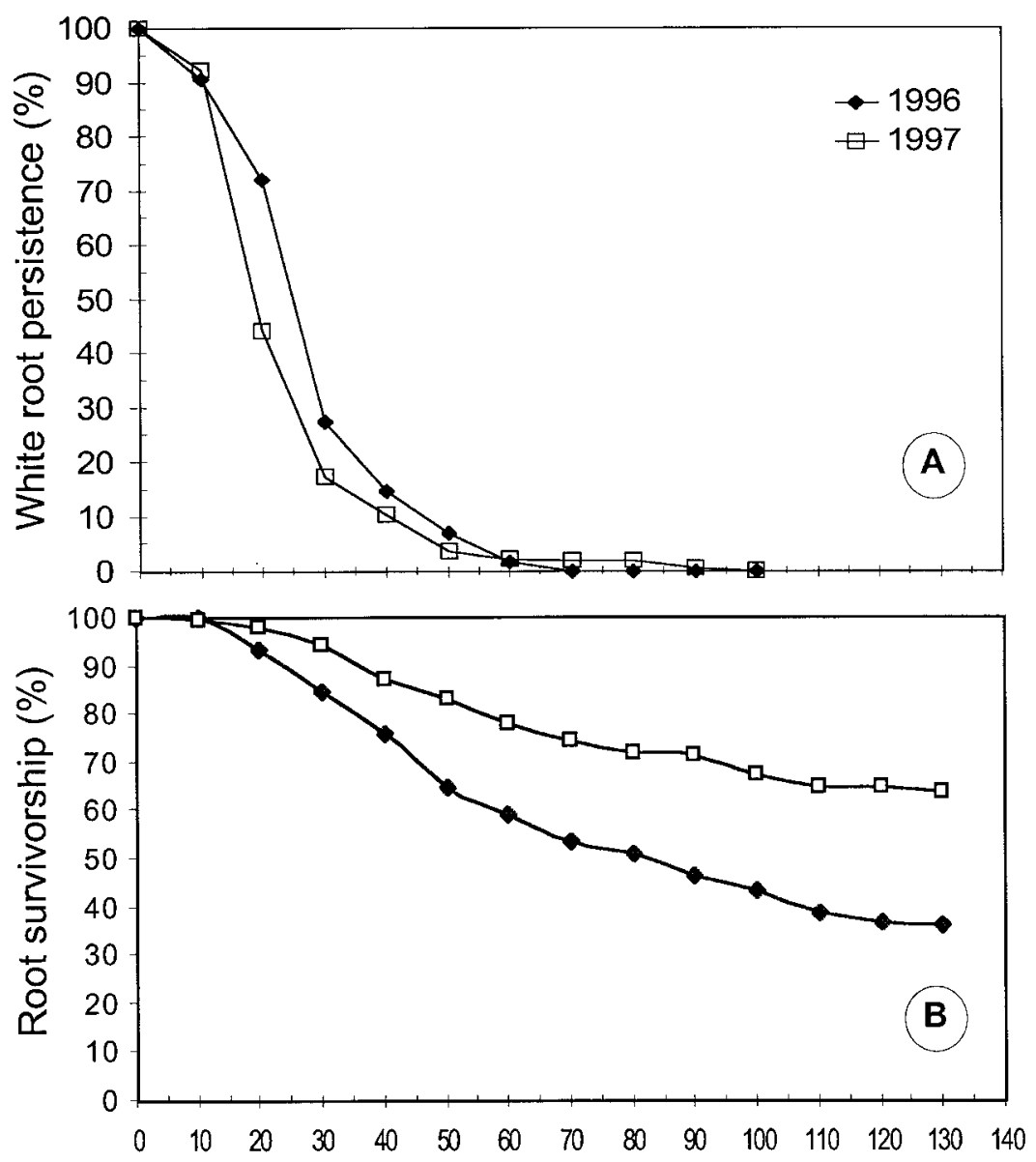

\section{Days}

Fig. 3. (A) The percentage of new white roots turning brown, and (B) percentage root survivorship from April to October 1996 and 1997, for field-grown 'Mutsu' apple trees on M.9 rootstock.

\section{Results}

Weather conditions. Data from a nearby meteorological station indicated substantial differences in precipitation and soil temperature during 1996 and 1997. Cumulative precipitation was greater in 1996 than 1997, especially from April to June, from midJuly to mid-August, and in October. Monthly precipitation was above the 30 -year norm of $9.2 \mathrm{~cm}$ per month for Ithaca, N.Y. during most of the 1996 growing season, and below normal for most of 1997. Soil temperatures at a $10-\mathrm{cm}$ depth were 2 to $4{ }^{\circ} \mathrm{C}$ higher during spring, and $\approx 5^{\circ} \mathrm{C}$ higher in late August and early September 1996, compared with the 1997 growing season.

FRUIT YIELD. Crop loads were similar each year, and trunk crosssectional area increased more in 1997 than in 1996, but there was no significant difference between yield efficiencies in the two growing seasons (Table 1). There was variation in size and crop load among trees, although it did not affect consistently total root counts or shoot growth of individual trees (data not presented).

Plant growth AND Phenology. Only a few woody roots were visible contiguous with minirhizotron tubes immediately after installation in late May 1996. A total of 273 and 285 new roots were recorded subsequently in the 15 observation tubes during 1996 and 1997, respectively. New root counts per tube per growing season ranged from 4 to 51 , but we attributed these different root densities to random differences in tree root distance from the observation tubes, not to any apparent differences in tree size, vigor or location.

Full bloom occurred 4 d earlier in 1996 compared to 1997 (21 May vs. 25 May, respectively). Shoot extension growth began $\approx 30 \mathrm{~d}$ before new root emergence in 1996, then shoot growth rates declined briefly and rebounded as root growth rates increased from mid-June to mid-July 1996 (Fig. 1A and B). Although their main growth peaks were offset, there was a substantial temporal overlap of new root and shoot growth during June and July. Maximum fruit growth rates occurred in June, coinciding with high rates of root emergence; fruit growth rates then declined gradually until harvest on 26 Oct. 1996. The first new roots appeared in early June; root emergence rates peaked early in July, then declined steadily until the end of August and remained low through the end of the growing season (Fig. 1B). Root turnover (decay or disappearance) increased as root emergence declined, several weeks after the first new roots had emerged. Turnover rates increased thereafter to a maximum in late August 1997, then declined during September and early October, with a smaller peak observed in late October 1996 on some trees.

Root and shoot growth rates and periodicity in 1997 were generally similar to 1996 (Fig. 2A and B). We began root observations on 14 Apr. 1997, and even though 65 roots from the previous year remained, no new roots were observed until 10 June 1997. Root emergence rates peaked on 20 June 1997 , two weeks earlier than in 1996. Unlike the previous summer, a second peak of root emergence was observed from mid-August to mid-September 1997. As in 1996, maximum shoot growth rates occurred from late May to mid-June 1997, preceding the maximum of root emergence. Although shoot growth was declining as root growth rates increased, there was some overlap of relatively high root and shoot growth rates (Fig. 2A and B). Root senescence and decay began in early July, $\approx 20 \mathrm{~d}$ after the first new roots had emerged. Turnover rates peaked during the latter half of August 1997, but the maximum rate was much lower than in 1996.

All of the new white roots that emerged each year turned brown and/or senesced before the end of their first growing season, with $50 \%$ of them turning brown after $25 \mathrm{~d}$ in 1996 and $19 \mathrm{~d}$ in 1997 (Fig. 3A). The proportion of newly emerged roots still present at the end of October was 38\% in 1996 and $64 \%$ in 1997 (Fig. 3B). The apparent half-life (number of days to 50\% mortality) of roots was $80 \mathrm{~d}$ in 1996 , and $>130 \mathrm{~d}$ in 1997 . Of the 104 emergent roots in the first year's cohort that turned brown but persisted until our last observations on 23 Oct. 1996, 63\% overwintered and were present at the initial minirhizotron recordings on 14 Apr. 1997. As roots matured or senesced from white to brown, the cortical tissue sloughed off and root diameter decreased; thus, the relative percentage of roots $<1 \mathrm{~mm}$ in diameter increased toward the end of each growing season. Root diameter was not consistently related with root longevity, because thicker roots $(>1 \mathrm{~mm})$ often disappeared during the growing season and fine roots $(<1 \mathrm{~mm})$ often remained viable and overwintered, as noted previously by Rogers (1939).

ROOT GROWTH DISTRIBUTION BY SOIL DEPTH. In both growing seasons, most of the roots observed were in the upper $25 \mathrm{~cm}$ soil 


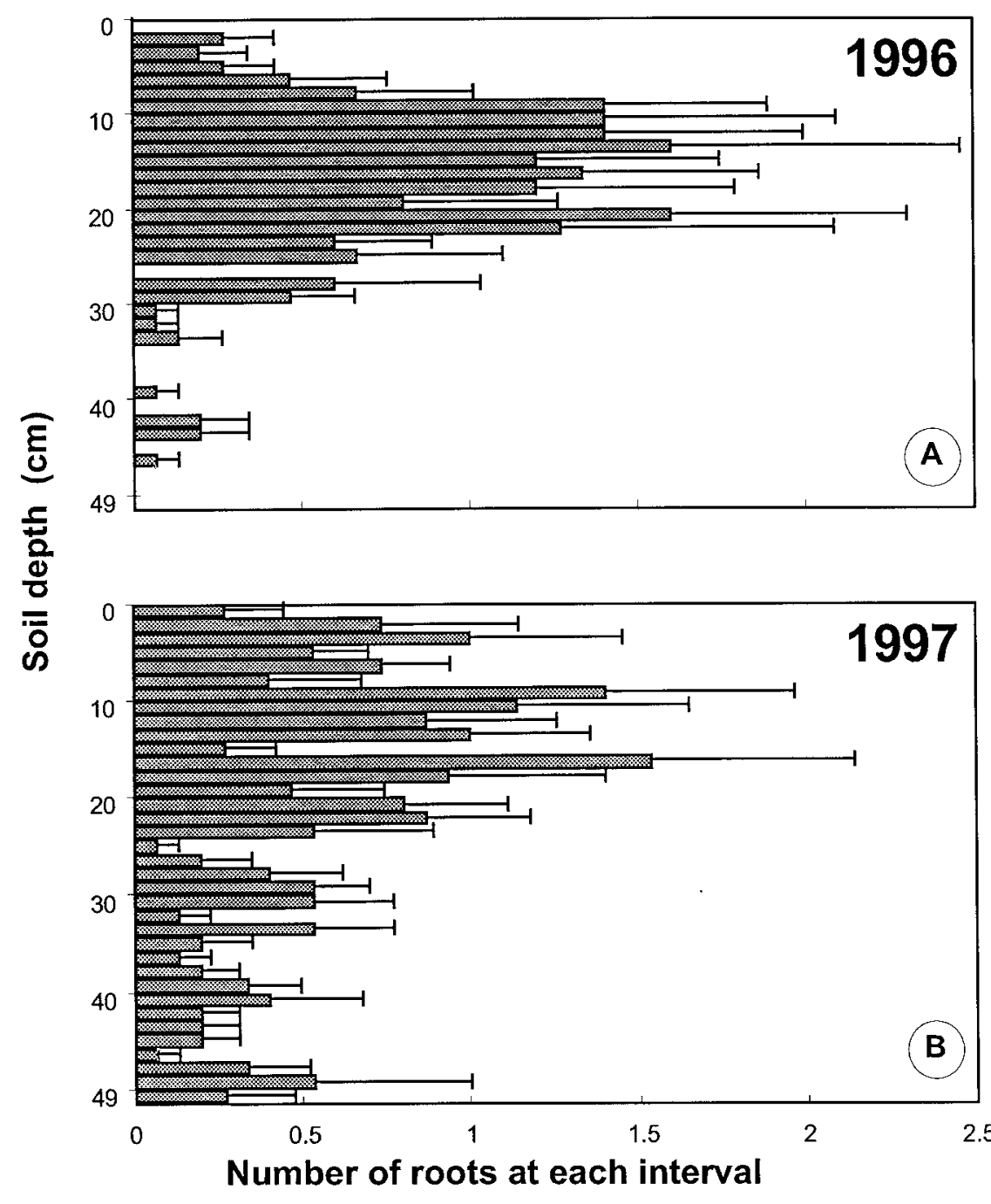

Fig. 4. Vertical distribution of roots observed in soil depth intervals from 0 to 50 cm in (A) 1996 and (B) 1997. Bars represent the mean of total root counts each year $\pm \mathrm{sE}$, based on observations in 15 minirhizotron tubes under 'Mutsu' trees on $\mathrm{M} .9$ rootstocks in a silt-loam soil.

profile (Fig. 4A and B), and relatively more root growth occurred in lower soil depths after midsummer (Fig. 5A and B). There was also more root growth from a 22 to 49-cm depth during 1997 compared with 1996, due to a second peak of new root emergence in August and September 1997 (Figs. 1B, 2B, and 5B). No roots were observed in repeated observations from 50 to $85 \mathrm{~cm}$ depths in the soil of this orchard.

Root SIZE DISTRIBUTION. Most of the white and brown roots remained <1 mm in diameter during both years, although in 1997 there were more fine roots, compared to 1996 (Fig. 6). Root size distributions observed in minirhizotron tubes in the present study were similar to size distributions we obtained by destructive harvesting of M.9 rootstocks in a simultaneous experiment with potted apple trees at this same orchard (Psarras and Merwin, 2000).

RHIZOSPHERE AND SOIL RESPIRATION. Regression analyses of the relationship between soil or soil-root respiration rates and soil temperatures indicated significant correlations between these variables in both years of observations (based on data from Figs. $1 \mathrm{C}$ and $2 \mathrm{C}$ ). For rhizosphere respiration vs. soil temperatures the linear regression $r^{2}, P$, and $\mathrm{Q}_{10}$ values were 0.36 , 0.01 , and 2.30 , respectively in 1996 , and 0.59 , 0.002 , and 2.33, respectively in 1997. Subtracting the baseline respiration values measured in soil without roots from comparable values in rhizosphere soil on the same dates in 1997, suggested that root-dependent respiration was also coupled with and sensitive to soil temperatures $\left(r^{2}, P\right.$, and $\mathrm{Q}_{10}$ values of $0.55,0.004$, and 3.1 , respectively).

Root growth, root turnover, and soil-root respiration rates did not vary in unison. In 1996, there were three maxima in soil-root respiration: one in mid-June when new root growth was just beginning, a second in late July when root growth was declining, and a third from late August to early September, during maximum root turnover (Fig. 1B and C). In 1997, rhizosphere respiration first peaked in late June after the major peak in new root emergence, and a second peak occurred in mid-August when root growth was declining but root turnover rates were high (Fig. 2B and C). The maximum soil-root $\mathrm{CO}_{2}$ respiration rates observed were $7 \mu \mathrm{mol} \cdot \mathrm{m}^{-2} \cdot \mathrm{s}^{-1}$ in late June 1997 , and $4.6 \mu \mathrm{mol} \cdot \mathrm{m}^{-2} \cdot \mathrm{s}^{-1}$ in $\mathrm{mid}-\mathrm{June}, 1996$. On a few occasions, rhizosphere $\mathrm{CO}_{2}$ respiration values as high as $15 \mu \mathrm{mol} \cdot \mathrm{m}^{-2} \cdot \mathrm{s}^{-1}$ were recorded at individual PVC collars.

\section{Discussion}

ROOT GROWTH PERIODICITY. We did not observe the bimodal root growth patterns reported by Head (1966, 1967, 1969); others have also failed to corroborate his results. Atkinson (1980), summarized reports of one to five peaks in apple root growth during a single growing season, presumably reflecting the influence of different climates, soil conditions, cultural practices and scion or rootstock genotypes. Similar trends in root growth have been reported for plum (Prunus domestica L.), sweet cherry (Prunus avium L.), and pear (Pyrus communis L.) (Atkinson and Wilson, 1980; Head, 1967, 1968a).

Genotypic traits of M.9 rootstock, and cold, saturated soil conditions during late spring are probable explanations for the periodicity and distribution of root growth in our study. Rogers (1939) reported that root growth of 14-year-old 'Lane's Prince Albert' apple trees started earlier on M.16 (vigorous) compared to M.9 (dwarfing) in two of four growing seasons. In the same study, root growth on M.9 occurred mostly during summer, with little activity during spring. Atkinson and Wilson (1980) reported minimal root growth before initiation of shoot growth of 'Golden Delicious' apple trees on M.9. In contrast, Head (1966) observed some root growth in April for 'Cox' apple on M.9, although it was less than the main peak of root growth in late June.

Apart from internal factors like rootstock genotype and scion vigor, root growth may also be affected by soil temperature and soil moisture. According to Rogers (1939), there is negligible root growth of apple below $6{ }^{\circ} \mathrm{C}$. This temperature threshold was not attained until late April at our experimental site, where soil remained saturated with water until mid-May. Interestingly, the soil temperature $\mathrm{Y}$ intercept for root-dependent respiration in our 


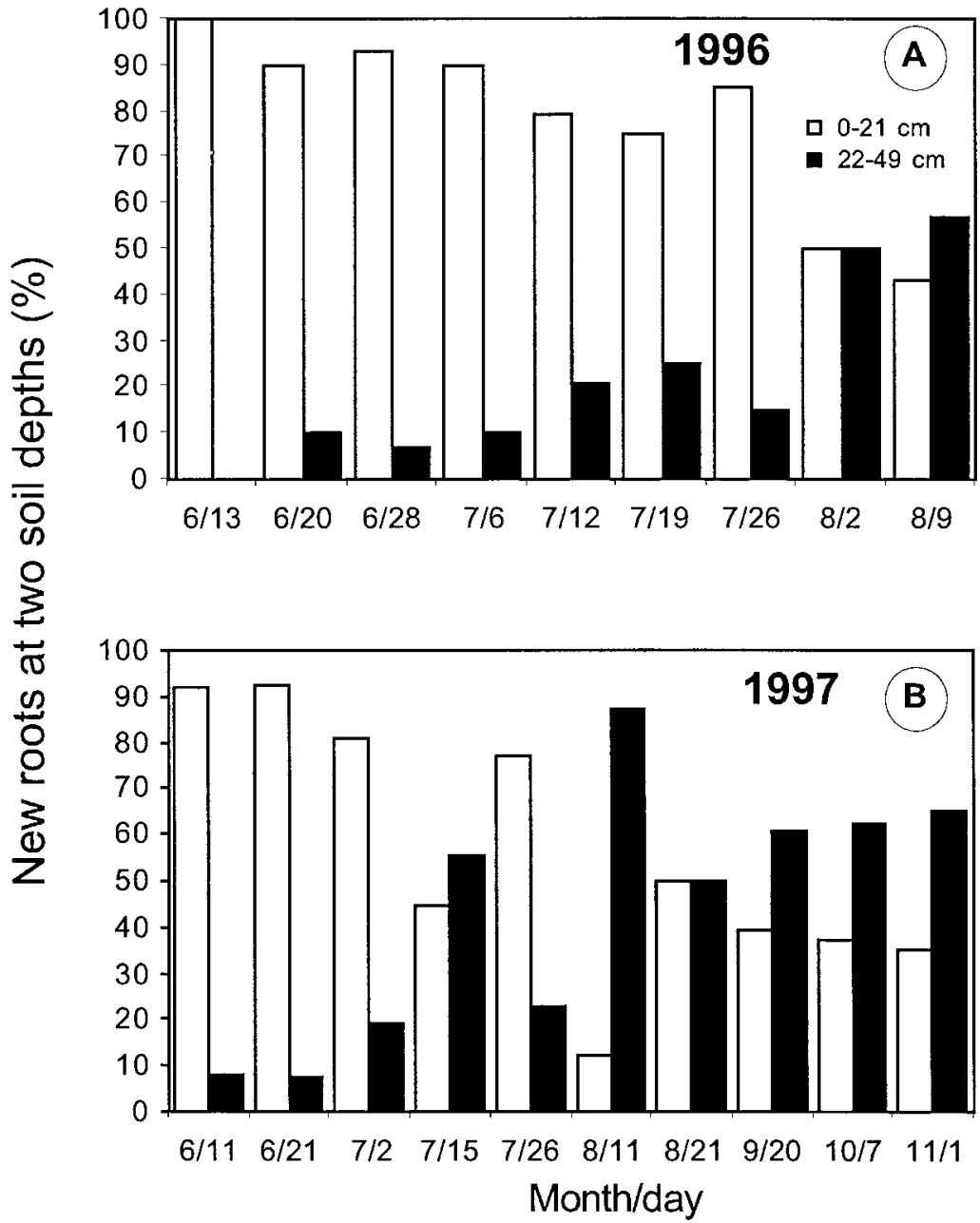

Fig. 5. Percentage of all new roots observed during (A) 1996 and (B) 1997 from 0 to $21 \mathrm{~cm}$ (white) and 22 to $49 \mathrm{~cm}$ (black) in the soil profile, for young fieldgrown 'Mutsu' trees on M.9 rootstocks.

regression model was $5^{\circ} \mathrm{C}$, suggesting that root respiration would be negligible below that temperature. Climate effects may explain the late initiation of root growth by our trees compared with previous reports from other regions.

Maximum root turnover rates differed substantially but occurred in late summer both years. Higher rates of root turnover have been reported previously for deciduous fruit trees. Wells and Eissenstat (1996) found that only $30 \%$ of apple roots developed in autumn survived the winter or lived past $200 \mathrm{~d}$, while Reid et al. (1993) reported that only $31 \%$ of kiwifruit roots survived more than $56 \mathrm{~d}$, and only $8 \%$ lived more than $252 \mathrm{~d}$. These observations suggest that root turnover represents a substantial portion of carbon allocation to the root systems of apple trees.

The limitation of root growth by a relatively shallow compacted soil layer at our site was consistent with observations in trench transect studies of Fernandez et al. (1995), and another study by Merwin et al. (1994) in an adjacent orchard with similar soil conditions. Restriction or variation of root growth at different soil depths and times has also been reported for apple and peach [Prunus persica (L.) Batsch. (Peach Group)] trees (Coker, 1958; Cripps, 1970; Glenn and Welker, 1993).

RHIzOSPHERE RESPIRATION. Root-soil respiration has been estimated previously for apple trees, but the different methods used by researchers make comparisons problematic. Ebert and Lenz (1991) reported increased respiration rates during summer for potted 3-year-old 'Elstar' apple on M.9 rootstocks, with a single peak in early August. Buwalda et al. (1992) also observed a single respiration peak in excised root systems of potted apple trees grown in sand, with a maximum early in June. Blanke (1996, 1997b) conducted in situ measurements of $\mathrm{CO}_{2}$ efflux on orchard soils from September to May in Germany. Our measurements were more frequent and prolonged than previous studies, and revealed multiple peaks in rhizosphere respiration that were not tightly coupled with observed soil temperature, root growth and root turnover rates.

Maximum soil-root $\mathrm{CO}_{2}$ respiration rates in the present study were considerably lower than the rate of $27 \mu \mathrm{mol} \cdot \mathrm{m}^{-2} \cdot \mathrm{s}^{-1}$ observed by Blanke $(1997 \mathrm{~b})$ on a hot day from a soil surface at $42{ }^{\circ} \mathrm{C}$. Soil temperatures at a $10-\mathrm{cm}$ depth never exceeded $25{ }^{\circ} \mathrm{C}$ in our measurements, and the maximum $\mathrm{CO}_{2}$ respiration rates of 4.6 and $7.0 \mu \mathrm{mol} \cdot \mathrm{m}^{-2} \cdot \mathrm{s}^{-1}$ in 1996 and 1997 were comparable to an upper rate of $5.9 \mu \mathrm{mol} \cdot \mathrm{m}^{-2} \cdot \mathrm{s}^{-1}$ reported by Proctor et al. (1976). Estimation and interpretation of rhizosphere respiration are complicated by many factors. Efflux of $\mathrm{CO}_{2}$ from the soil surface reflects metabolic activity of various organisms and decomposition of soil organic matter in the sampled zone. Root respiration itself may represent metabolism for maintenance of existing tissues, new root growth, or activity related to nutrient uptake, each of which is affected by several biotic and abiotic factors (Buwalda, 1993; Lambers et al., 1996). Ben Asher et al. (1994 a, 1994b) reported close correlation between $\mathrm{CO}_{2}$ efflux from the soil surface and root biomass under the sampled area of an almond orchard. We also observed significant correlation between rhizosphere respiration and total

Fig. 6. Proportion of all roots in various diameter classes during 1996 and 1997 for field-grown 'Mutsu' apple trees on M.9 rootstock. Bars represent means \pm SE bars for 15 trees.

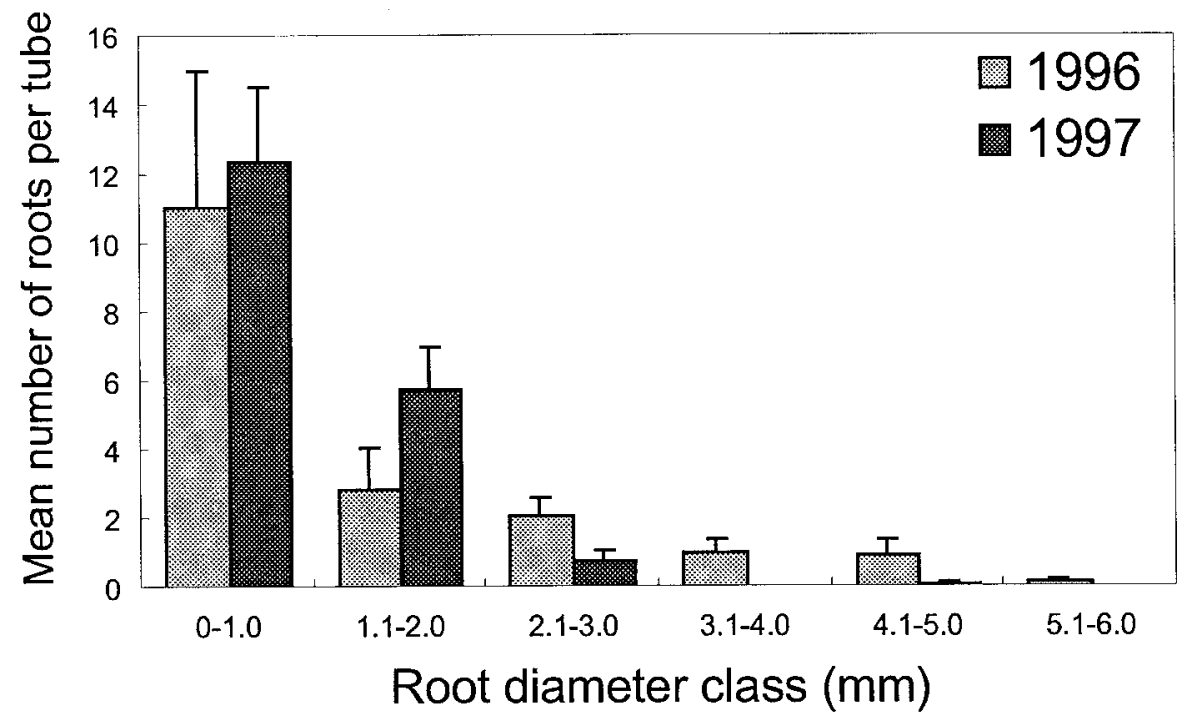


root biomass of potted apple trees in another experiment (Psarras and Merwin, 2000). Considering that trunk cross sectional area increased from 1996 to 1997 , it is reasonable to assume a net increase in total root biomass of young trees during this time span. These observations suggest that the observed increase in rhizosphere respiration from 1996 to 1997 reflected actual trends in root biomass and metabolic activity.

Microbial respiration accounts for part of measured soil-root respiration in field soils, and can be estimated by comparing $\mathrm{CO}_{2}$ efflux in soil with and without roots. Soil respiration rates in our rootless control pots averaged $50 \%$ less than in soil with tree roots early and late in the growing season, but decreased to $27 \%$ in midJune when new root emergence rates were high (Figs. 1C and 2C). These values were similar to those reported by Proctor et al. (1976), where respiration from soil without roots averaged $37 \%$ and ranged from $21 \%$ to $54 \%$ of combined soil-root respiration. Soil microbial respiration may also increase in the presence of roots, because root turnover and exudates provide nutrients for microbial metabolism (Head, 1968b; Rogers, 1968).

New root emergence rates peaked in mid-to-late June, several weeks after the main phase of shoot extension growth for young apple trees on M.9 rootstocks, during consecutive growing seasons with different weather conditions. Rhizosphere respiration rates paralleled soil temperatures early and late in the growing season, but were not tightly coupled with new root growth or root turnover rates. Long-term survival of roots was low, and new root growth or root turnover represented substantial allocations of carbohydrates for young apple trees. The observed root growth periodicity and rhizosphere respiration patterns indicated a relatively high demand for nutrients during early to midsummer in orchards on M.9 rootstocks, which has important practical implications for rational tree fruit and pest management.

\section{Literature Cited}

Atkinson, D. 1980. The distribution and effectiveness of the roots of tree crops. Hort. Rev. 2:424-490.

Atkinson, D. and S.A. Wilson. 1980. The growth and distribution of fruit tree roots: Some consequences for nutrient uptake, p. 137-150. In: D. Atkinson, J.E. Jackson, R.O. Sharples, and W.M. Waller (eds.). The mineral nutrition of fruit trees. Butterworths, United Kingdom.

Ben-Asher, J., G. Cardon, D. Peters, D.E. Rolston, J.W. Biggar, C.J. Phene, and J.E. Ephrath. 1994a. Determining root activity distribution by measuring carbon dioxide fluxes. Soil Sci. Soc. Amer. J. 58:926930.

Ben-Asher, J., G. Cardon, D. Peters, D.E. Rolston, C.J. Phene, J.W. Biggar, and R.B. Hutmacher. 1994b. Determining almond root zone from surface carbon dioxide fluxes. Soil Sci. Soc. Amer. J. 58:930934.

Blanke, M.M. 1996. Soil respiration in an apple orchard. Environ. Expt. Bot. 36:339-348.

Blanke, M.M. 1997a. Means and measurement of root respiration in fruit crops. Acta Hort. 451:327-335.

Blanke, M.M. 1997b. Contribution of soil respiration to the carbon balance of an apple orchard. Acta Hort. 451:337-344.

Bloomfield, J., K. Vogt, and P.M. Wargo. 1996. Tree root turnover and senescence, p. 363-381. In: Y. Waisel, A. Eshel, and U. Kafkafi (eds.).
Plant roots: The hidden half. Marcel Dekker, New York.

Buwalda J.G. 1993. The carbon cost of root systems of perennial fruit crops. Environ. Expt. Bot. 33:131-140.

Buwalda, J.G., M. Fossen, and F. Lenz. 1992. Carbon dioxide efflux from roots of calamodin and apple. Tree Physiol. 10:391-401.

Coker, E.G. 1958. Root studies XII. Root systems of apple on Malling rootstocks on five soil series. J. Hort. Sci. 33:71-79.

Cripps, J.E.L. 1970. A seasonal pattern of apple root growth in Western Australia. J. Hort. Sci. 45:153-161.

Ebert, G. and F. Lenz. 1991. Annual course of root respiration of apple trees and its contribution to the CO2-balance. Gartenbauwissenschaft 56:130-133.

Fernandez, R.T., R.L. Perry, and D.C. Ferree. 1995. Root distribution patterns of nine apple rootstocks in two contrasting soil types. J. Amer. Soc. Hort. Sci. 120:6-13.

Glenn, D.M. and W.V. Welker. 1993. Root development patterns in field grown peach trees. J. Amer. Soc. Hort. Sci. 118:362-365.

Head, G.C. 1966. Estimating seasonal changes in the quantity of white unsuberized roots on fruit trees. J. Hort. Sci. 41:197-206.

Head, G.C. 1967. Effects of seasonal changes in shoot growth on the amount of unsuberized roots on apple and plum trees. J. Hort. Sci. 42:169-180.

Head, G.C. 1968a. Seasonal changes in the amounts of white unsuberized roots on pear trees on quince rootstock. J. Hort. Sci. 43:49-58.

Head, G.C. 1968b. Seasonal changes in the diameter of secondarily thickened roots of fruit trees in relation to growth of other parts of the tree. J. Hort. Sci. 43:275-282.

Head, G.C. 1969. The effects of fruiting and defoliation on seasonal trends in new root production on apple trees. J. Hort. Sci. 44:75-181.

Head, G.C. 1973. Shedding of roots, p. 237-293. In: T.T. Kozlowski (ed.). Shedding of plant parts. Academic Press, New York.

Lambers, H., O.K. Atkin, and I. Scheurwater. 1996. Respiratory patterns in roots in relation to their functioning, p. 323-362. In: Y. Waisel, A. Eshel, and U. Kafkafi (eds.). Plant roots: The hidden half. Marcel Dekker, New York.

McMichael, B.L. and H.M. Taylor. 1987. Applications and limitations of rhizotrons and minirhizotrons, p. 1-13. In: H.M. Taylor (ed.). Minirhizotron observation tubes: Methods and applications for measuring rhizosphere dynamics. Amer. Soc. Agron. Spec. Publ. 50.

Merwin, I. A., W.C. Stiles, and H.M. van Es. 1994. Orchard groundcover management impacts on soil physical properties. J. Amer. Soc. Hort. Sci. 119:216-222.

Proctor, J.T.A., R.L. Watson, and J.J. Landsberg. 1976. The carbon balance of a young apple tree. J. Amer. Soc. Hort. Sci. 101:579-582.

Psarras, G. 1999. Effects of water and nutrient stresses on morphological and physiological characteristics of apple roots. PhD. diss., Cornell Univ., Ithaca, N.Y.

Psarras, G. and I.A. Merwin. 2000. Water stress affects rhizosphere respiration rates and root morphology of young 'Mutsu' apple trees on M.9 and MM.111 rootstocks. J. Amer. Soc. Hort. Sci. (in press).

Reid, J.B., I. Sorensen, and R.A. Petrie. 1993. Root demography in kiwifruit (Actinidia deliciosa). Plant Cell Environ. 16:949-957.

Rogers, W.S. 1939. Root studies VIII. Apple root growth in relation to rootstock, soil, seasonal and climatic factors. J. Hort. Sci. 17:99-130.

Rogers, W.S. 1968. Amount of cortical and epidermal tissue shed from roots of apple. J. Hort. Sci. 43:527-528.

Rogers, W.S. and G.C. Head. 1969. Factors affecting the distribution and growth of roots of perennial woody species, p. 111-148. In: W.J. Whittington (ed.). Root growth. Butterworths, United Kingdom

Wells, C.E. and D.M. Eissenstat. 1996. Fine root production and mortality in apple over winter. HortScience 31:603. 